\title{
Formation of novel spiro, spiroansa and dispiroansa derivatives of cyclotetraphosphazene from the reactions of polyfunctional amines with octachlorocyclotetraphosphazatetraene
}

\author{
HANIFE İBIŞOĞLU, ${ }^{a *}$ GÖNÜL YENILMEZ ÇİFTÇİ, ${ }^{a}$ ADEM KILIÇ, ${ }^{a}$ \\ ESRA TANRIVERDİ, ${ }^{\mathrm{a}}$ ILKER ÜN, ${ }^{a}$ HAKAN DAL ${ }^{\mathrm{b}}$ and TUNCER HÖKELEK ${ }^{\mathrm{c}}$ \\ ${ }^{a}$ Department of Chemistry, Gebze Institute of Technology, Gebze 41400, Kocaeli, Turkey \\ ${ }^{b}$ Department of Chemistry, Anadolu University, Eskișehir 26470, Turkey \\ ${ }^{\mathrm{c}}$ Department of Physics, Hacettepe University, Beytepe, Ankara 06800, Turkey \\ e-mail: ibisoglu@gyte.edu.tr
}

MS received 18 June 2008; revised 21 November 2008

\begin{abstract}
Nucleophilic substitution reactions of $\mathrm{N}_{4} \mathrm{P}_{4} \mathrm{Cl}_{8}$, with di-, tri-, and tetra-functional reagents such as $\mathrm{N}$-methyl-1,3-propanediamine, $\mathrm{N}, \mathrm{N}^{\prime}$-methyl-1,3-propanediamine, spermidine and spermine were investigated in this study. Six novel products were isolated whose structures have been characterized by elemental analysis, mass spectrometry, ${ }^{1} \mathrm{H}$ and ${ }^{31} \mathrm{P}$ NMR spectroscopy. The structure of (11) was investigated by X-ray crystallography.
\end{abstract}

Keywords. Cyclotetraphosphazenes; ${ }^{31} \mathrm{P}$ NMR spectroscopy; amino phosphazenes; spiro-phosphazene; X-ray.

\section{Introduction}

Phosphazenes are important compounds from which a large number of organophosphazenes can be derived by the reaction with nucleophiles. Organophosphazenes find a variety of applications in science and technology ${ }^{1}$ including hydraulic fluids and lubricants, ${ }^{2,3}$ electrical conductivity, ${ }^{4}$ ionic liquids, ${ }^{5}$ liquid crystalline materials, ${ }^{6}$ tumour growth inhibitor, ${ }^{7}$ ferroelectric and non-linear optical polymers, ${ }^{8 a}$ biomedical materials, ${ }^{9}$ membrane polymer solid electrolytes, drug carrier, and flame retardents, ${ }^{10,11}$ etc. Furthermore, chiral substituted cyclophosphazenes in principle should also be useful as bases in chiral catalysis and for chiral polymers. ${ }^{8 b}$ Some aminocyclophosphazenes such as octapyrrolidinocyclotetraphosphazene ${ }^{12}$ have significant anticancer reagents ${ }^{13}$ and some of them are also used as antimicrobial agents. ${ }^{14}$ The reactions of hexachlorocyclotriphosphazatriene, $\mathrm{N}_{3} \mathrm{P}_{3} \mathrm{Cl}_{6}$, with di-, tri- and tetra-functional amines have been extensively studied $^{15-18}$ and especially large difunctional diamines were reported for a potential value in cancer chemotherapy as selective carriers for delivering antican-

*For correspondence cer drugs to malignant target cells. ${ }^{19,20}$ Although, a large number of octachlorocyclotetraphosphazatetraene (1), $\mathrm{N}_{4} \mathrm{P}_{4} \mathrm{Cl}_{8}$, with monofunctional amines were prepared and studied, ${ }^{21-31}$ discussion on a substitution with polyfunctional amines is relatively limited in the literature. ${ }^{32-37}$

We report here, the synthesis and structural characterization of six new cyclotetraphosphazene derivatives (scheme 1) and, to the best of our knowledge, there is no report so far of any derivative in this series that has been structurally characterized by any spectral data or x-ray crystallography.

\section{Experimental}

\subsection{Materials}

Octachlorocyclotetraphosphazatetraene (a gift from the Otsuka Chemical Co. Ltd.) was purified by fractional crystallization from $n$-hexane. Spermidine (Fluka 99.0\%) and spermine (Fluka 99.0\%), N,N'Methyl-1,3-propanediamine (Fluka 97.0\%), NMethyl-1,3-pro-panediamine (Alfa Aesar 99.0\%) were used as received. The following chemicals were obtained from Merck; $\mathrm{CH}_{2} \mathrm{Cl}_{2}(\geq 99.0 \%), n$ hexane ( $\geq 99.0 \%), \quad \mathrm{CHCl}_{3} \quad(99 \cdot 0-99.4 \%), \quad$ THF 


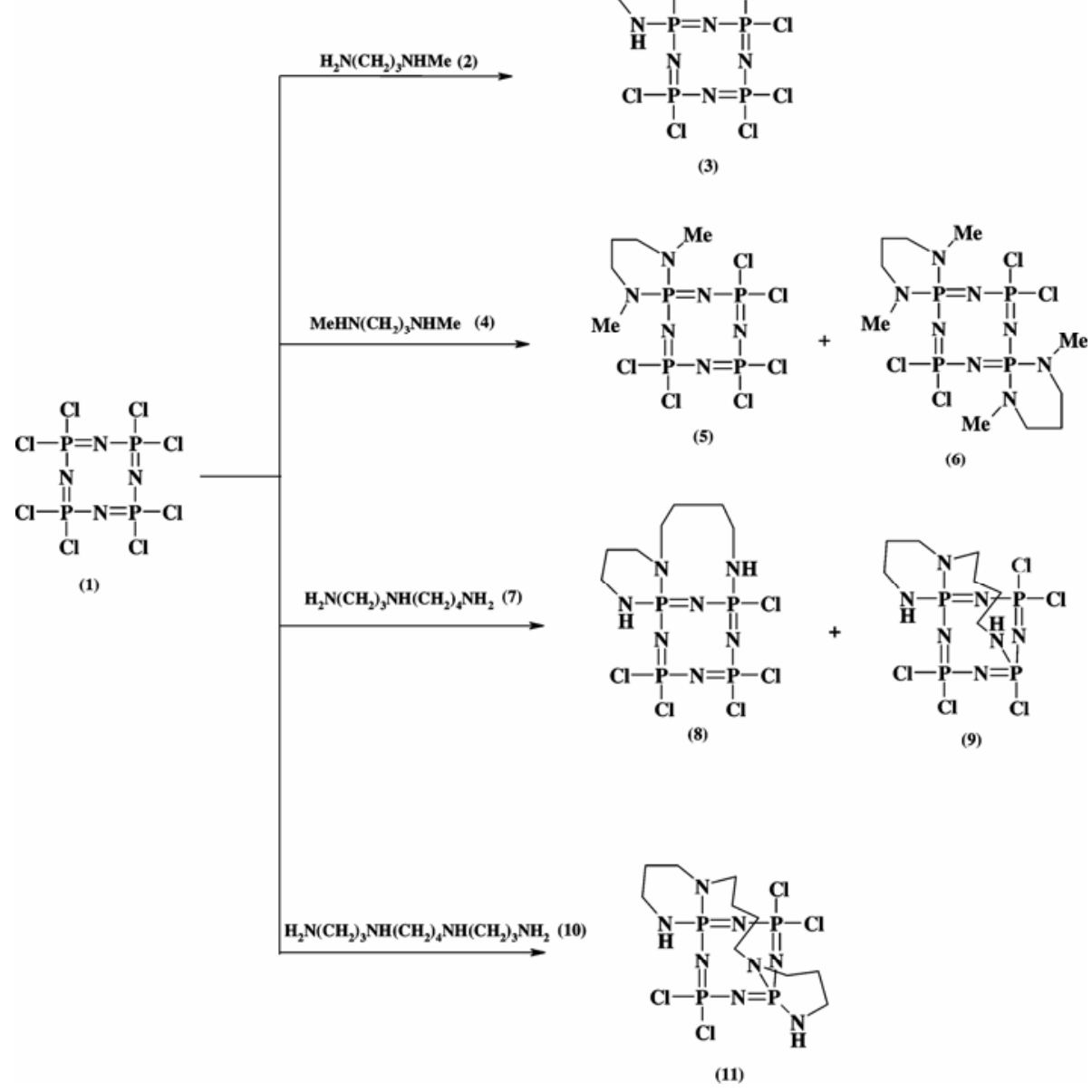

Scheme 1. The synthesis of cyclotetraphosphazene derivatives.

( $\geq 99.0 \%$ ). THF was distilled over a sodium-potassium alloy under an atmosphere of dry argon. All solvents used in this work were purified by conventional methods. The deuteriated solvent $\left(\mathrm{CDCl}_{3}\right)$ for NMR spectroscopy was obtained from Goss Scientific.

\subsection{Methods}

Elemental analyses were obtained using a Carlo Erba 1106 Instrument. Mass spectra were an Bruker MicrOTOF LC/MS spectrometer using Electro Spray Ionisation (ESI); ${ }^{35} \mathrm{Cl}$ values were used for calculated masses. Analytical thin layer chromatography (TLC) was performed on silica gel (Merck, Kieselgel 60, 0.25 mm thickness) with $\mathrm{F}_{254}$ indicator. Column chromatography was performed on silica gel (Merck, Kieselgel 60, 70-230 mesh; for $3 \mathrm{~g}$ crude mixture, $100 \mathrm{~g}$ silica gel was used in a column of $3 \mathrm{~cm}$ in diameter and $60 \mathrm{~cm}$ in length). ${ }^{1} \mathrm{H}$ and ${ }^{31} \mathrm{P}$
NMR spectra were recorded in $\mathrm{CDCl}_{3}$ solutions on a Varian INOVA $500 \mathrm{MHz}$ spectrometer using TMS as an internal reference for ${ }^{1} \mathrm{H} \mathrm{NMR}$ and $85 \% \mathrm{H}_{3} \mathrm{PO}_{4}$ as an external reference for ${ }^{31} \mathrm{P}$.

\subsection{Synthetic procedures}

2.3a Synthesis of $8,8,10,10,12,12$-hexachloro-1methyl-1, 5, 7, 9, 11, 13-hexaaza-6 $\lambda^{5}, 8 \lambda^{5}, 10 \lambda^{5}$, $12 \lambda^{5}$-tetraphosphaspiro [5.7]trideca-6, 8, 10, 12tetraene (3): A solution of (1) $(3 \mathrm{~g}, 6.4 \mathrm{mmol})$ in THF $70 \mathrm{~mL}$ was added drop-wise to a stirred solution of (2) $(1.14 \mathrm{~g}, 12.8 \mathrm{mmol})$ in THF $30 \mathrm{~mL}$. The reaction mixture was stirred under an atmosphere of argon at room temperature for a further 3 days and then N-methyl-1, 3-propanediamine dihydrochloride was filtered off and the solvent was removed under reduced pressure at $30^{\circ} \mathrm{C}$, and the resulting colourless oil was subjected to column chromatography, using $n$-hexane-dichloromethane $(1: 3)$ as eluent. 
Table 1. Analytical data of cyclotetraphosphazenes.

\begin{tabular}{|c|c|c|c|c|c|c|c|c|c|}
\hline \multirow[b]{3}{*}{ Comp. } & \multirow[b]{3}{*}{ Formula } & \multicolumn{6}{|c|}{ Anal. data (\%) } & & \\
\hline & & \multicolumn{3}{|c|}{ Calculated } & \multicolumn{3}{|c|}{ Found } & \multicolumn{2}{|c|}{ MASS } \\
\hline & & $\mathrm{N}$ & $\mathrm{C}$ & $\mathrm{H}$ & $\mathrm{N}$ & $\mathrm{C}$ & $\mathrm{H}$ & {$[\mathrm{M}+\mathrm{H}]^{+}$} & M \\
\hline 3 & $\mathrm{C}_{4} \mathrm{H}_{10} \mathrm{Cl}_{6} \mathrm{~N}_{6} \mathrm{P}_{4}$ & $17 \cdot 55$ & $10 \cdot 03$ & $2 \cdot 11$ & $17 \cdot 51$ & $10 \cdot 00$ & $2 \cdot 07$ & $478 \cdot 9$ & 478 \\
\hline 5 & $\mathrm{C}_{5} \mathrm{H}_{12} \mathrm{Cl}_{6} \mathrm{~N}_{6} \mathrm{P}_{4}$ & $17 \cdot 05$ & $12 \cdot 19$ & $2 \cdot 45$ & $17 \cdot 15$ & $12 \cdot 22$ & $2 \cdot 48$ & $492 \cdot 9$ & 492 \\
\hline 6 & $\mathrm{C}_{10} \mathrm{H}_{24} \mathrm{Cl}_{4} \mathrm{~N}_{8} \mathrm{P}_{4}$ & $21 \cdot 46$ & $23 \cdot 01$ & 4.63 & $21 \cdot 50$ & 23.09 & $4 \cdot 66$ & $523 \cdot 1$ & 522 \\
\hline 8 & $\mathrm{C}_{7} \mathrm{H}_{16} \mathrm{Cl}_{5} \mathrm{~N}_{7} \mathrm{P}_{4}$ & $19 \cdot 63$ & $16 \cdot 84$ & $3 \cdot 23$ & $19 \cdot 68$ & $16 \cdot 81$ & $3 \cdot 25$ & $500 \cdot 0$ & 499 \\
\hline 9 & $\mathrm{C}_{7} \mathrm{H}_{16} \mathrm{Cl}_{5} \mathrm{~N}_{7} \mathrm{P}_{4}$ & $19 \cdot 63$ & $16 \cdot 84$ & $3 \cdot 23$ & $19 \cdot 67$ & $16 \cdot 79$ & $3 \cdot 26$ & $500 \cdot 1$ & 499 \\
\hline 11 & $\mathrm{C}_{10} \mathrm{H}_{22} \mathrm{Cl}_{4} \mathrm{~N}_{8} \mathrm{P}_{4}$ & $21 \cdot 55$ & $23 \cdot 10$ & $4 \cdot 26$ & $21 \cdot 51$ & $23 \cdot 13$ & $4 \cdot 22$ & $521 \cdot 1$ & 520 \\
\hline
\end{tabular}

One product was (3) (yield $11 \%$, m.p. $119-120^{\circ} \mathrm{C}$ ) isolated as white powder. ${ }^{1} \mathrm{H}$ NMR: $\delta=3.1 \mathrm{ppm}(m$, $2 \mathrm{H}, \mathrm{NCH}_{2}$ (spiro) $), \delta=2 \cdot 8-3.2 \mathrm{ppm}\left(m, 2 \mathrm{H}, \mathrm{NHCH}_{2}\right.$ (spiro)), $\delta=2.7 \mathrm{ppm}\left(s, 3 \mathrm{H}, \mathrm{CH}_{3}\right), \delta=1.5 \mathrm{ppm}(m$, $2 \mathrm{H}, \mathrm{CH}_{2}$ (spiro)); $2.5 \mathrm{ppm}(s, 1 \mathrm{H}, \mathrm{NH})$.

2.3b Synthesis of 8, 8, 10, 10, 12, 12-hexachloro-1, 5-dimethyl-1, 5, 7, 9, 11, 13-hexaaza-6 $\lambda^{5}, 8 \lambda^{5}, 10 \lambda^{5}$, $12 \lambda^{5}$-tetraphosphaspiro [5.7]trideca-6, $8, \quad 10, \quad 12-$ tetraene (5) and 8, 8, 17,17-tetrachloro-1,5,11,15tetramethyl-1, 5, 7, 9, 11, 15, 16, 18-octaaza-6 $\lambda^{5}$, $8 \lambda^{5}, \quad 10 \lambda^{5}, \quad 17 \lambda^{5}$-tetraphosphadispiro[5.3.5.3]octadeca-6 (18), 7, 9, 16-tetraene (6): A solution of (1) $(2 \mathrm{~g}, 4.3 \mathrm{mmol})$ in THF $70 \mathrm{~mL}$ was added drop-wise to a stirred solution of (4) $(0.88 \mathrm{~g}, 8.6 \mathrm{mmol})$ in THF $30 \mathrm{~mL}$. The reaction mixture was stirred under an atmosphere of argon at room temperature for a further 3 days and then $\mathrm{N}, \mathrm{N}^{\prime}$-methyl-1,3-propanediamine dihydrochloride was filtered off and the solvent was removed under reduced pressure at $30^{\circ} \mathrm{C}$ and the resulting colourless oil was subjected to column chromatography, using $\mathrm{CH}_{2} \mathrm{Cl}_{2}$ - $n$-hexane (3:1) as eluent. Compound (5) (yield 18\%, m.p. $\left.>250{ }^{\circ} \mathrm{C}\right)$ is white powder. ${ }^{1} \mathrm{H}$ NMR: $\delta=3.1 \mathrm{ppm}(m$, $4 \mathrm{H}, \mathrm{NCH}_{2}$ (spiro)), $\delta=2.7 \mathrm{ppm}\left(s, 6 \mathrm{H}, \mathrm{CH}_{3}\right)$, $\delta=1.5 \mathrm{ppm}\left(\mathrm{m}, 2 \mathrm{H}, \mathrm{CH}_{2}\right.$ (spiro)) and (6) (yield 6\%) is viscous oil. ${ }^{1} \mathrm{H}$ NMR: $\delta=3.1 \mathrm{ppm}\left(m, 8 \mathrm{H}, \mathrm{NCH}_{2}\right.$ (spiro)), $\delta=2.7 \mathrm{ppm}\left(s, 12 \mathrm{H}, \mathrm{CH}_{3}\right), \delta=1.5 \mathrm{ppm}(m$, $4 \mathrm{H}, \mathrm{CH}_{2}$ (spiro)).

2.3c Synthesis of 2, 2, 4, 4, 6-pentachloro-6, 8, 9, $10,11,14,15,16$-octahydro-7H,13H-17, 6-epiazeno- $2 \lambda^{5}, 4 \lambda^{5}, 6 \lambda^{5}, 17 \lambda^{5}-[1,3,2]$ diazaphosphinino $[1,2-a][1,3,5,7,9,2,4,6,8]$ pentaazatetraphosphacyclotridecine (8) and 2, 2, 4, 17, 17-pentachloro-4, 6, 7, 8, 9, 12, 13, 14-octahydro-5H, 11H15 , 4-(epiazenophosphenoazeno)- $2 \lambda^{5}, 4 \lambda^{5}, 15 \lambda^{5}-[1$,
3, 2]diazaphosp-hinino[1, 2-a][1, 3, 5, 7, 2, 4, 6]tetraazatriphosphacycloundecine (9): A solution of (1) $(2 \mathrm{~g}, 4.31 \mathrm{mmol})$ in $\mathrm{CHCl}_{3} 60 \mathrm{~mL}$ was added drop-wise to a stirred solution of (7) (1.25 g, $8.63 \mathrm{mmol}$ ) in $\mathrm{CHCl}_{3} 60 \mathrm{~mL}$. The reaction mixture was stirred under an atmosphere of argon at room temperature for a further 3 days and then spermidine trihydrochloride was filtered off and the solvent was removed under reduced pressure at $30^{\circ} \mathrm{C}$, and the resulting colourless oil was subjected to column chromatography, using $\mathrm{CH}_{2} \mathrm{Cl}_{2}-n$-hexane $(4: 1)$ as eluent. Compound (8) (yield $21 \%$, m.p. $177^{\circ} \mathrm{C}$ ) was recrystallized from $\mathrm{CH}_{2} \mathrm{Cl}_{2}-n$-hexane $(1: 1) .{ }^{1} \mathrm{H}$ NMR: $\delta=3.2 \mathrm{ppm}\left(m, 4 \mathrm{H}, \mathrm{NHCH}_{2}\right.$ (bridge) $), \delta=$ $3.1 \mathrm{ppm}\left(m, 4 \mathrm{H}, \mathrm{NHCH}_{2}\right.$ (spiro) and $\mathrm{NCH}_{2}$ (spiro)), $\delta=2.3 \mathrm{ppm} \quad\left(m, 2 \mathrm{H}, \quad \mathrm{NCH}_{2} \quad\right.$ (bridge) $), \quad \delta=1.5-$ $1.1 \mathrm{ppm}(\mathrm{m}, 4 \mathrm{H} \mathrm{CH}$ (bridge) $) ; 2.5 \mathrm{ppm}(s, 2 \mathrm{H}, \mathrm{NH})$. Compound (9) (yield 3\%) was isolated as viscous oil. ${ }^{1} \mathrm{H}$ NMR: $\delta=3.2 \mathrm{ppm}\left(m, 4 \mathrm{H}, \mathrm{NHCH}_{2}\right.$ (bridge)), $\delta=3.0 \mathrm{ppm}\left(m, 4 \mathrm{H}, \mathrm{NHCH}_{2}\right.$ (spiro) and $\mathrm{NCH}_{2}$ (spiro)), $\delta=2.4 \mathrm{ppm} \quad\left(m, 2 \mathrm{H}, \quad \mathrm{NCH}_{2}\right.$ (bridge)), $\delta=1.5-1.3 \mathrm{ppm}\left(m, 4 \mathrm{H} \mathrm{CH}_{2}\right.$ (bridge) ); $2.5 \mathrm{ppm}(s$, $2 \mathrm{H}, \mathrm{NH})$.

2.3d Synthesis of 17, 17, 19, 19-tetrachloro-1, 2, 3, $4,7,8,11,12,13,14-$ decahydro- $6 H, 9 H-15,21-$ epiazeno-15 $\lambda^{5}, 17 \lambda^{5}, 19 \lambda^{5}, 21 \lambda^{5}$-bis $[1,3,2]$ diazaphosphinino [1, 2-a:2', 1'-h][1, 3, 5, 7, 9, 2, 4, 6, 8]pentaazatetraphosphacyclotridecine (11): A solution of (1) $(2 \mathrm{~g}, 4.31 \mathrm{mmol})$ in $\mathrm{CHCl}_{3} 60 \mathrm{~mL}$ was added dropwise to a stirred solution of (10) (1.75 g, $4.31 \mathrm{mmol}$ ) in $\mathrm{CHCl}_{3} 60 \mathrm{~mL}$. The reaction mixture was stirred under an atmosphere of argon at room temperature for a further 3 days and then spermine tetrahydrochloride was filtered off and the solvent was removed under reduced pressure at $30^{\circ} \mathrm{C}$, and the resulting colourless oil was subjected to column 
chromatography, using $n$-hexane-THF $(2: 1)$ as eluent. Compound (11) (Yield 15\%, m.p.: $>250^{\circ} \mathrm{C}$ ) was recrystallized from $\mathrm{CH}_{2} \mathrm{Cl}_{2}-n$-hexane $(1: 1) .{ }^{1} \mathrm{H}$ NMR: $\delta=3 \cdot 1-3 \cdot 2 \mathrm{ppm}\left(m, 8 \mathrm{H}, \mathrm{NCH}_{2}\right.$ (spiro)); $2 \cdot 2-$ $2.3 \mathrm{ppm}\left(m, 4 \mathrm{H}, \mathrm{NCH}_{2}\right.$ (bridge) $) ; 1.5 \mathrm{ppm}(m, 4 \mathrm{H}$, $\mathrm{CH}_{2}$ (bridge)); $1.4 \mathrm{ppm}$ ( $m, 4 \mathrm{H}, \quad \mathrm{CH}_{2}$ (spiro));
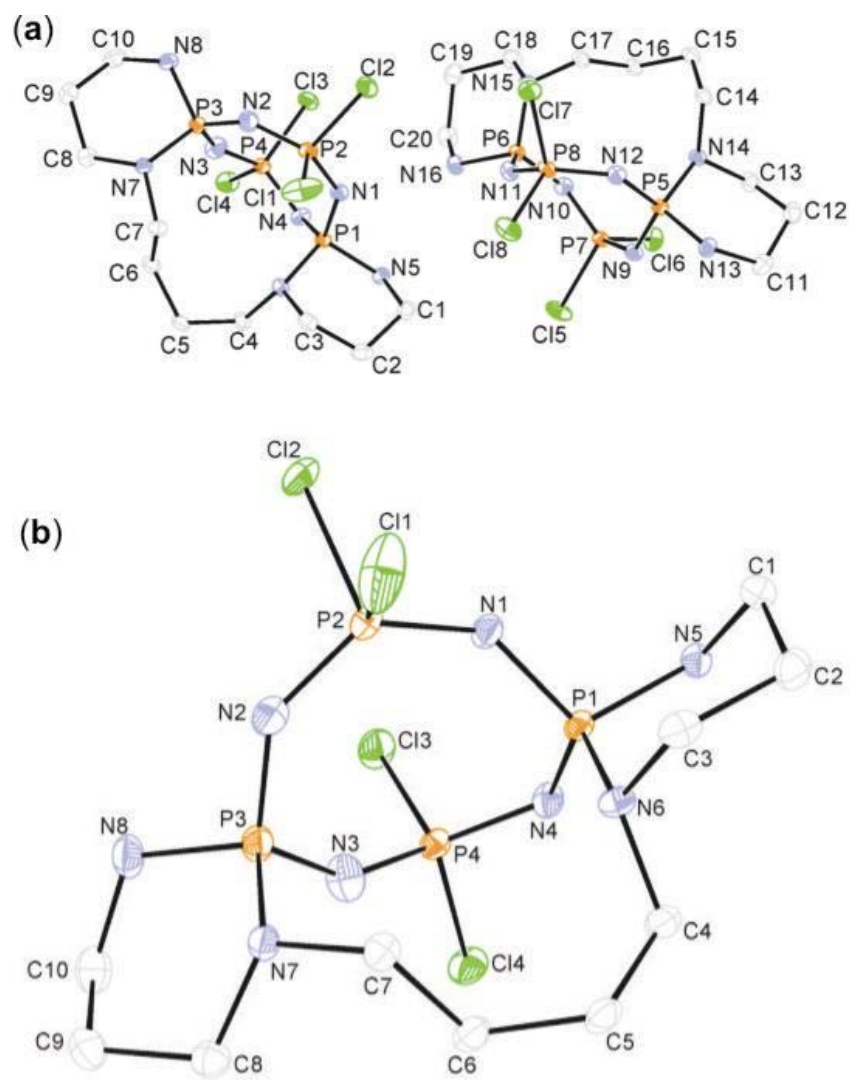

(c)

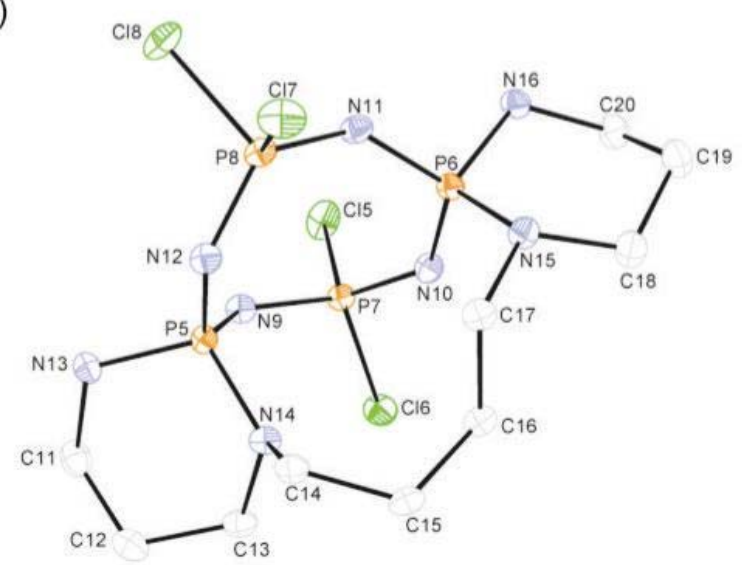

Figure 1. a. An $\mathrm{ORTEP}^{40}$ drawing of the asymmetric unit with the atom-numbering scheme. Displacement ellipsoids are drawn at the $50 \%$ probability level. b, c, ORTEP $^{40}$ drawings of each molecules in the asymmetric unit with the atom -numbering scheme. Displacement ellipsoids are drawn at the $50 \%$ probability level.
$2.5 \mathrm{ppm}(s, 2 \mathrm{H}, \mathrm{NH})$. Analytical data of these compounds are given in table 1.

\section{$2.4 \quad$ X-Ray crystallography}

Colourless crystals of (11) were crystallized from $\mathrm{CH}_{2} \mathrm{Cl}_{2}-n$-hexane. The molecular structure of compound along with the atom-numbering schemes are depicted in figures $1 \mathrm{a}-\mathrm{c}, 2 \mathrm{a}$ and $2 \mathrm{~b}$. Crystallographic data are listed in table 2 and selected bond lengths and angles are given in table 3. Crystallographic data were collected on a Bruker Kappa APEXII diffractometer using $\mathrm{MoK}_{\alpha}$ radiation $(\lambda=0.71073 \AA)$ at $T=100(2) \mathrm{K}$. Absorption correction by multi$\operatorname{scan}^{38}$ was applied. Structure was solved by direct
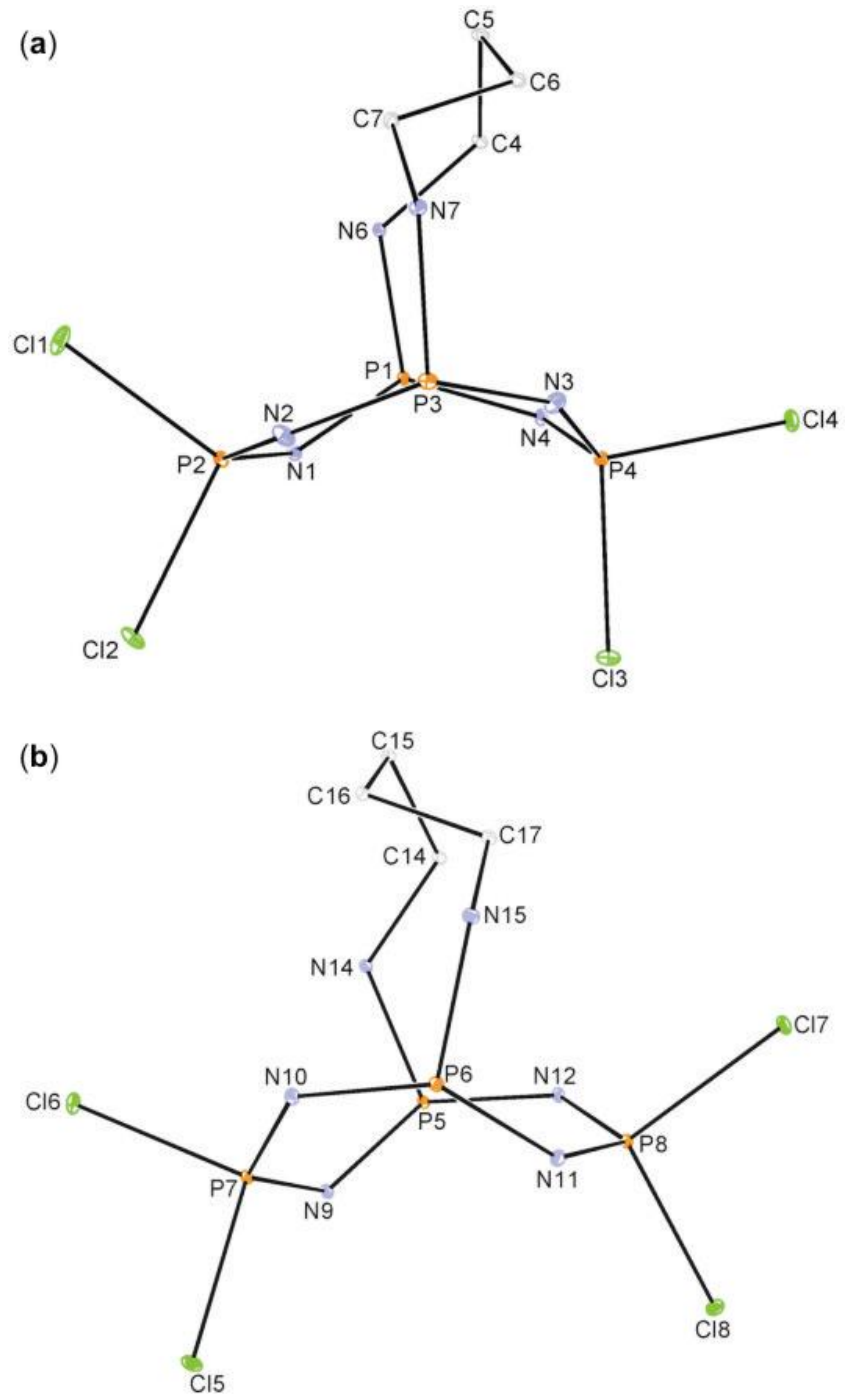

Figure 2. a, b. The conformations of the phosphazene and the macro ring for each molecule in the asymmetric unit with the atom-numbering scheme. 
methods $^{39}$ and refined by full-matrix least squares against $\mathrm{F}^{2}$ using all data. ${ }^{39}$ All non-H atoms were refined anisotropically. The $\mathrm{H}$ atom positions were calculated geometrically at distances of $0.97 \AA$ $\left(\mathrm{CH}_{2}\right)$ from the parent $\mathrm{C}$ atoms; a riding model was used during the refinement process and the $U_{\text {iso }}(\mathrm{H})$ values were constrained to be $1.2 U_{\text {eq }}$ (carrier atom).

\section{Results and discussion}

\subsection{Synthesis}

The reactions of $\mathrm{N}_{4} \mathrm{P}_{4} \mathrm{Cl}_{8}$ with polyfunctional (di-, tri- and tetra-functional) amines were studied in four sections:

(i) The compound (3) was synthesized from the reaction of $\mathrm{N}_{4} \mathrm{P}_{4} \mathrm{Cl}_{8}$ with (2) at $1: 2$ molar ratio in dry THF for three days at room temperature under argon atmosphere;

(ii) Compounds (5) and (6) were obtained from the reaction of $\mathrm{N}_{4} \mathrm{P}_{4} \mathrm{Cl}_{8}$ with (4) at the same experimental condition of (i).

(iii) The cyclotetraphosphazene derivatives (8) and (9) were synthesized from the reaction $\mathrm{N}_{4} \mathrm{P}_{4} \mathrm{Cl}_{8}$ with (7) at 1:2 molar ratio at room temperature in $\mathrm{CHCl}_{3}$ for three days;

(iv) The compound (11) was synthesized from the reaction of $\mathrm{N}_{4} \mathrm{P}_{4} \mathrm{Cl}_{8}$ with (10) at the same experimental condition of (iii).

Table 2. Crystallographic data of (11).

\begin{tabular}{ll}
\hline Empirical formula & $\mathrm{C}_{10} \mathrm{H}_{20} \mathrm{Cl}_{4} \mathrm{~N}_{8} \mathrm{P}_{4}$ \\
$F w$ & $518 \cdot 02$ \\
Crystal system & monoclinic \\
Space group & $P n$ \\
$a(\AA)$ & $12 \cdot 683(2)$ \\
$b(\AA)$ & $12 \cdot 777(4)$ \\
$c(\AA)$ & $12 \cdot 706(3)$ \\
$\alpha\left({ }^{\circ}\right)$ & $90 \cdot 00$ \\
$\beta\left({ }^{\circ}\right)$ & $92 \cdot 86(3)$ \\
$\gamma\left({ }^{\circ}\right)$ & $90 \cdot 00$ \\
$V\left(\AA^{3}\right)$ & $2056 \cdot 5(9)$ \\
$Z$ & 4 \\
$\mu\left(\mathrm{cm}^{-1}\right)$ & $0 \cdot 902\left(\mathrm{MoK}_{\alpha}\right)$ \\
$\left.\rho(\mathrm{calcd})(\mathrm{g} \mathrm{cm})^{-1}\right)$ & $1 \cdot 673$ \\
Number of reflections total & 121009 \\
Number of reflections unique & 10957 \\
$R_{\text {int }}$ & $0 \cdot 0407$ \\
$2 \theta_{\text {max }}\left({ }^{\circ}\right)$ & $59 \cdot 30$ \\
$T_{\min } / T_{\max }$ & $0 \cdot 655 / 0 \cdot 763$ \\
Number of parameters & 470 \\
$R\left[F^{2}>2 \sigma\left(F^{2}\right)\right]$ & $0 \cdot 0323$ \\
$w R$ & $0 \cdot 0778$ \\
\hline
\end{tabular}

The preparation and spectral data of monospirobino-(12), bis-spirobinospermidine (13) and dispirobinospermine cyclotetraphosphazene (14) derivatives have been reported elsewhere. ${ }^{35}$ (iii) and (iv) are different methods which were employed for the synthesis of (12), (13) and (14).

In this work, the spectral data of (12), (13) and (14) are given for comparison purposes in table 4.

Compounds (3), (5), (8) and (11) were obtained as white solids while (6) and (9) were obtained as viscous oils. In general, all products, especially the compounds (6) and (9), were obtained in low yields after purification using a silica gel column. The reason for the low yield is attributed to the reactivity of the $\mathrm{P}-\mathrm{Cl}$ bonds. After substitution of one of the chlorine atoms, the remaining $\mathrm{P}-\mathrm{Cl}$ bonds become very reactive and give multiple substituted products. Also, due to the structural flexibility of $\mathrm{N}_{4} \mathrm{P}_{4} \mathrm{Cl}_{8}$, the eight-membered ring is significantly more reactive than the planar six-membered trimer ring. ${ }^{10,23,41}$ Although several minor multiple substituted products, which were detected by TLC using $\mathrm{CH}_{2} \mathrm{Cl}_{2}-n$ hexane $(1: 1)$ as mobile phase, were different from the main products (3), (5), (6), (8), (9) and (11), separation of these minor products could not be achieved by column chromatography. Compounds (3), (5) and (6) were found to be stable air whereas products obtained from the reaction of $\mathrm{N}_{4} \mathrm{P}_{4} \mathrm{Cl}_{8}$ with $\mathrm{N}$-methylethanolamine, 1, 2-diaminoethane were unstable in the earlier study. ${ }^{33}$ (8), (9) and (11) were also found to be stable air.

\subsection{Spectroscopy}

Compounds (3), (5), (6), (8), (9) and (11) were characterized by elemental analysis, mass spectrometry and ${ }^{1} \mathrm{H}$ and ${ }^{31} \mathrm{P}$ NMR spectroscopy. The MS spectra of phosphazene derivatives show the protonated $(\mathrm{M}+\mathrm{H})^{+}$peaks and the elemental analysis results are in good agreement with the proposed structures as shown in scheme 1 (table 1).

The ${ }^{31} \mathrm{P}$ NMR spectral data of (3), (5), (6), (8), (9), (11) are given in table 4.

The proton decoupled ${ }^{31} \mathrm{P}$ NMR spectrum $\left(\mathrm{A}_{4}\right.$ type) of $\mathrm{N}_{4} \mathrm{P}_{4} \mathrm{Cl}_{8}$ shows a singlet in figure $3 \mathrm{a}$ because of the chemical environment equivalence of all the phosphorus nuclei.

The proton decoupled ${ }^{31} \mathrm{P}$ NMR spectrum of the compound (3) in figure $3 \mathrm{~b}$ exhibits an $\mathrm{ABC}_{2}$ type spectrum due to three different phosphorus environments within the molecule. The chemical shifts and 
<smiles>ClP1(Cl)=NP(Cl)(Cl)=NP(Cl)(Cl)=NP(Cl)(Cl)=NP(Cl)(Cl)=NP(Cl)(Cl)=NP(Cl)(Cl)=N1</smiles>

(12)<smiles>ClP1(Cl)=NP(Cl)(Cl)=NP2(Cl)=NN(CCCCN[PH]3(Cl)N=P(Cl)(Cl)NCCCN3)P(Cl)(=NP(Cl)(Cl)=N2)P=N1</smiles>

(13)<smiles>ClP1(Cl)=NP(Cl)(Cl)=NP2(=NP(Cl)(Cl)=N1)NCCCN2CCCCCN1CCCNP12=NP(Cl)(Cl)=NP(Cl)(Cl)=N2</smiles>

(14)

Table 3. The selected bond lengths $(\AA)$ and angles $\left({ }^{\circ}\right)$ for (11).

\begin{tabular}{|c|c|c|c|}
\hline P1-N1 & $1.604(2)$ & P5-N9 & $1.600(2)$ \\
\hline P1-N4 & $1.594(2)$ & P5-N12 & $1 \cdot 588(2)$ \\
\hline P1-N5 & $1.665(2)$ & P5-N13 & $1.661(2)$ \\
\hline P1-N6 & $1.647(2)$ & P5-N14 & $1.655(2)$ \\
\hline P2-N1 & $1 \cdot 557(2)$ & P6-N10 & $1.600(2)$ \\
\hline P2-N2 & $1 \cdot 546(3)$ & P6-N11 & $1.589(2)$ \\
\hline $\mathrm{P} 2-\mathrm{Cl} 1$ & $2.0315(12)$ & P6-N15 & $1.661(2)$ \\
\hline $\mathrm{P} 2-\mathrm{Cl} 2$ & $2 \cdot 0051(11)$ & P6-N16 & $1.652(2)$ \\
\hline P3-N2 & $1.579(3)$ & P7-N9 & $1 \cdot 562(2)$ \\
\hline $\mathrm{P} 3-\mathrm{N} 3$ & $1.606(3)$ & P7-N10 & $1.554(2)$ \\
\hline P3-N7 & $1.659(2)$ & P7-C15 & $2 \cdot 0211(10)$ \\
\hline P3-N8 & $1.629(2)$ & P7-Cl6 & $2.0299(11)$ \\
\hline P4-N3 & $1.532(3)$ & P8-N11 & $1 \cdot 546(2)$ \\
\hline P4-N4 & $1.567(2)$ & P8-N12 & $1.565(2)$ \\
\hline $\mathrm{P} 4-\mathrm{Cl} 3$ & $2 \cdot 0350(10)$ & P8-C17 & $2 \cdot 0276(10)$ \\
\hline $\mathrm{P} 4-\mathrm{Cl} 4$ & $2 \cdot 0127(11)$ & P8-Cl8 & $2 \cdot 0132(10)$ \\
\hline N1-P1-N4 & $116 \cdot 09(12)$ & N9-P5-N12 & $119.09(12)$ \\
\hline N1-P1-N5 & $108 \cdot 39(12)$ & N9-P5-N14 & $108 \cdot 57(12)$ \\
\hline N4-P1-N6 & $112 \cdot 81(12)$ & N12-P5-N13 & $105.85(12)$ \\
\hline N5-P1-N6 & $104 \cdot 13(12)$ & N13-P5-N14 & $108 \cdot 71(12)$ \\
\hline N1-P2-N2 & $126 \cdot 08(13)$ & N10-P6-N11 & $116 \cdot 15(12)$ \\
\hline N3-P3-N2 & $115.49(14)$ & N10-P6-N15 & $109 \cdot 12(12)$ \\
\hline N2-P3-N8 & $106 \cdot 89(14)$ & N11-P6-N16 & $105 \cdot 36(12)$ \\
\hline N3-P3-N7 & $108 \cdot 29(13)$ & N15-P6-N16 & $105 \cdot 39(12)$ \\
\hline N7-P3-N8 & $102 \cdot 49(12)$ & N9-P7-N10 & $124 \cdot 16(12)$ \\
\hline N3-P4-N4 & $122 \cdot 89(13)$ & N11-P8-N12 & $123 \cdot 75(12)$ \\
\hline P1-N1-P2 & $138 \cdot 86(12)$ & P5-N9-P7 & $129 \cdot 15(15)$ \\
\hline P2-N2-P3 & $139 \cdot 02(17)$ & P6-N10-P7 & $133.42(16)$ \\
\hline P3-N3-P4 & 148.23 (19) & P6-N11-P8 & $137 \cdot 36(16)$ \\
\hline P1-N4-P4 & $127 \cdot 05(15)$ & P5-N12-P8 & $132 \cdot 28(15)$ \\
\hline C1-N5-P1 & $114 \cdot 65(17)$ & C11-N13-P5 & $113 \cdot 35(18)$ \\
\hline C3-N6-P1 & $112.95(17)$ & C13-N14-P5 & $112 \cdot 57(17)$ \\
\hline C3-N6-C4 & $113 \cdot 9(2)$ & C14-N14-P5 & $122 \cdot 70(18)$ \\
\hline C4-N6-P1 & $121 \cdot 64(18)$ & C13-N14-C14 & $115 \cdot 4(2)$ \\
\hline C7-N7-P3 & $115.87(17)$ & C18-N15-P6 & $117 \cdot 48(18)$ \\
\hline C8-N7-P3 & $115 \cdot 87(17)$ & C17-N15-P6 & $117 \cdot 10(18)$ \\
\hline C7-N7-C8 & $113 \cdot 1(2)$ & C17-N15-C18 & $114 \cdot 1(2)$ \\
\hline C10-N8-P3 & $115.93(19)$ & C20-N16-P6 & $115 \cdot 14(18)$ \\
\hline
\end{tabular}

the two coupling constant values of (Pspiro and $\mathrm{PCl}_{2}$ ) are similar to that of (12) and (13) (table 4). ${ }^{35}$ The proton coupled ${ }^{31} \mathrm{P}$ NMR spectrum (not shown) of (3) shows that the compound (2) replaces two the chlorine atoms in compound (1). The signals at ca.
$0.78 \mathrm{ppm}\left(\mathrm{P}_{\mathrm{A}}\right)$ are multiplet. The signals of $P_{\mathrm{B}}$ and $P_{\mathrm{C}}(\delta=-4.95$ and $-6.11 \mathrm{ppm})$ remain unchanged.

The proton decoupled ${ }^{31} \mathrm{P}$ NMR spectrum of the compound (5) in figure $3 \mathrm{c}$ exhibits an $\mathrm{ABC}_{2}$ type spectrum similar to that of compound (3). The 
Table 4. ${ }^{31} \mathrm{P}$ NMR parameters for cyclotetraphosphazenes.

\begin{tabular}{|c|c|c|c|c|c|c|c|c|}
\hline \multirow[b]{3}{*}{ Compd. } & \multirow[b]{3}{*}{ Ref. } & \multirow{2}{*}{\multicolumn{3}{|c|}{$\delta\left({ }^{31} \mathrm{P} \mathrm{NMR}\right)[\mathrm{ppm}]$}} & \multicolumn{3}{|c|}{${ }^{2} \mathrm{~J}(\mathrm{PP})[\mathrm{Hz}]$} & \multirow[b]{3}{*}{$\mathrm{PCl}_{2}-\mathrm{PCl}_{2}$} \\
\hline & & & & & \multirow{2}{*}{$\begin{array}{c}\mathrm{P}(\text { Nspiro })- \\
\mathrm{PCl}_{2}\end{array}$} & \multirow{2}{*}{$\begin{array}{l}\text { P(Nspiro)- } \\
\text { P(NHR) }\end{array}$} & \multirow{2}{*}{$\begin{array}{c}\mathrm{P}(\mathrm{NHR}) \mathrm{Cl} \\
\mathrm{PCl}_{2}\end{array}$} & \\
\hline & & $\mathrm{P}$ (Nspiro) & $\mathrm{P}(\mathrm{NHR}) \mathrm{Cl}$ & $\mathrm{PCl}_{2}$ & & & & \\
\hline 1 & This work & - & - & -5.4 & - & - & - & - \\
\hline 3 & This work & $0 \cdot 78$ & - & $\begin{array}{l}-4 \cdot 95 \\
-6 \cdot 11\end{array}$ & $27 \cdot 4$ & - & - & 27.8 \\
\hline 5 & This work & $3 \cdot 08$ & - & $\begin{array}{l}-5.07 \\
-8.54\end{array}$ & $27 \cdot 3$ & - & - & $26 \cdot 6$ \\
\hline 6 & This work & 3.53 & - & -8.94 & $27 \cdot 1$ & - & - & - \\
\hline 8 & This work & $0 \cdot 18$ & $6 \cdot 26$ & $\begin{array}{l}-1.37 \\
-3.71\end{array}$ & $26 \cdot 3$ & $39 \cdot 8$ & - & $22 \cdot 4$ \\
\hline 9 & This work & $8 \cdot 38$ & $-2 \cdot 09$ & -3.73 & $31 \cdot 2$ & - & 31.8 & - \\
\hline $\mathbf{1}$ & This work & 1.06 & - & $-3 \cdot 34$ & 28.5 & - & - & - \\
\hline 12 & 35 & $-0 \cdot 35$ & $-5 \cdot 2$ & $\begin{array}{l}-2 \cdot 8 \\
-6 \cdot 9 \\
-4 \cdot 4 \\
-7 \cdot 1\end{array}$ & $27 \cdot 6$ & - & $27 \cdot 3$ & $\begin{array}{l}38 \cdot 8 \\
33 \cdot 3\end{array}$ \\
\hline 13 & 35 & $6 \cdot 1$ & $-0 \cdot 1$ & $\begin{array}{l}-1 \cdot 6 \\
-3 \cdot 8\end{array}$ & $25 \cdot 5$ & $39 \cdot 15$ & - & $21 \cdot 9$ \\
\hline 14 & 35 & $-0 \cdot 6$ & - & $\begin{array}{l}-5 \cdot 3 \\
-7 \cdot 3\end{array}$ & $28 \cdot 0$ & - & - & $26 \cdot 85$ \\
\hline
\end{tabular}

chemical shift of $\mathrm{P}($ spiro $)\left(\mathrm{P}_{\mathrm{A}}\right)$ is $3.08 \mathrm{ppm}$ and this value is more downfield in contrast to that of (3) (table 4). The proton coupled ${ }^{31} \mathrm{P}$ NMR spectrum (not shown) of (5) is similar to that for compound (3).

The proton decoupled ${ }^{31} \mathrm{P}$ NMR spectrum $\left(\mathrm{A}_{2} \mathrm{X}_{2}\right.$ spin system) of (6) consisting of two triplets is shown in figure $3 \mathrm{~d}$. Based on the similar product, $\mathrm{N}_{4} \mathrm{P}_{4} \mathrm{Cl}_{4}\left[\mathrm{~N}(i-\mathrm{Pr})\left(\mathrm{CH}_{2}\right)_{3} \mathrm{~N}(i-\mathrm{Pr})\right]_{2}$, given in the literature, ${ }^{32}$ we suggest that the compound (6) should be the most possible product. The proton coupled ${ }^{31} \mathrm{P}$ NMR spectrum (not shown) indicates that two different singlets appear as multiplets $\left(P_{\mathrm{A}}\right)$ and triplet $\left(P_{\mathrm{X}}\right)$.

The ${ }^{2} \mathrm{~J}(\mathrm{P}-\mathrm{N}-\mathrm{P})$ values for compounds (3), (5), (6) are lower than that for $\mathrm{N}_{3} \mathrm{P}_{3} \mathrm{Cl}_{4}\left(\mathrm{HN}\left(\mathrm{CH}_{2}\right)_{3} \mathrm{~N}\left(\mathrm{CH}_{3}\right)\right]$. ${ }^{42 \mathrm{a}}$ It appears that this is a general trend for (amino) cyclophosphazenes. ${ }^{32,42 \mathrm{~b}}$

The proton decoupled ${ }^{31} \mathrm{P}$ NMR spectrum of the compound (8) in figure $4 \mathrm{a}$ gives an ABCD type spectrum because of four different phosphorus environments within the molecule. The compounds (12) and (13) had two $\mathrm{A}_{2} \mathrm{BC}$ and two ABCD types spectra in earlier work, respectively. ${ }^{35}$ The doublet at $\delta=-3.71 \mathrm{ppm}$ is caused by $\mathrm{PCl}_{2}$ group $\left(P_{\mathrm{D}}\right)$ in figure $4 \mathrm{a}$ and the coupling constant of this group was calculated as ${ }^{2} \mathrm{JP}_{\mathrm{C}} \mathbf{P}_{\mathrm{D}}=22.4 \mathrm{~Hz}$ (table 4). The proton coupled ${ }^{31} \mathrm{P}$ NMR spectrum of (8) show that the spermidine replaces three chlorine atoms in compound (1). The signals at ca. $0.18 \mathrm{ppm}\left(\mathrm{P}_{\mathrm{A}}\right)$ and $6.26 \mathrm{ppm}\left(P_{\mathrm{B}}\right)$ are seen as multiplets and the signals of $\mathrm{PCl}_{2}$ groups $(\delta=-1.37$ and $-3.71 \mathrm{ppm})$ remain unchanged (figure $4 \mathrm{~b}$ ).

The proton decoupled ${ }^{31} \mathrm{P}$ NMR spectrum $\left(\mathrm{ABC}_{2}\right.$ spin system) of compound (9) possessing three sets of triplets corresponding to the Pspiro $\left(P_{\mathrm{A}}\right)$, $\mathrm{P}(\mathrm{NHR}) \mathrm{Cl}\left(\mathrm{P}_{\mathrm{B}}\right)$ and the $\mathrm{PCl}_{2}$ groups $\left(P_{\mathrm{C}}\right)$ are shown in figure $5 \mathrm{a}$. The proton coupled ${ }^{31} \mathrm{P}$ NMR spectrum (not shown) of (9) indicates that the multiplets corresponds to Pspiro group $(\delta=8.38 \mathrm{ppm})$ and (NHR)Cl group $(\delta=-2.09 \mathrm{ppm})$. The signals of the $\mathrm{PCl}_{2}$ groups $(\delta=-3.73 \mathrm{ppm})$ remain unchanged.

The proton decoupled spectrum of (11) in figure $5 \mathrm{~b}$ has an $\mathrm{A}_{2} \mathrm{~B}_{2}$ spectrum. The spin system of this spectrum is different from (14) (ABCD type $)^{35}$ since the two triplets are seen at ca. $\left(\delta=1.06\left(P_{\mathrm{A}}\right)\right.$ (PNspiro) and $\left.-3.34 \mathrm{ppm}\left(\mathrm{P}_{\mathrm{B}}\right)\left(\mathrm{PCl}_{2}\right)\right)$, but the two coupling constant of $\mathrm{P}\left(\mathrm{Nspiro}-\mathrm{PCl}_{2}\right)\left(\mathrm{P}_{\mathrm{A}} \mathrm{P}_{\mathrm{B}}\right)$ is $28.5 \mathrm{~Hz}$ similar to that of (14) ${ }^{35}$ The proton coupled ${ }^{31} \mathrm{P}$ NMR spectrum (not shown) of (11) shows that the spermine replaces four chlorine atoms in compound (1). Two different singlets are seen as multiplets $\left(P_{\mathrm{A}}\right)$ and triplet $\left(P_{\mathrm{B}}\right)$.

\subsection{X-ray analysis}

In order to further corroborate the structural assignments, single crystal X-ray structure of compound (11) is reported. The asymmetric unit contains two crystallographically independent molecules as given in figures la-c, respectively. The phosphazene con- 


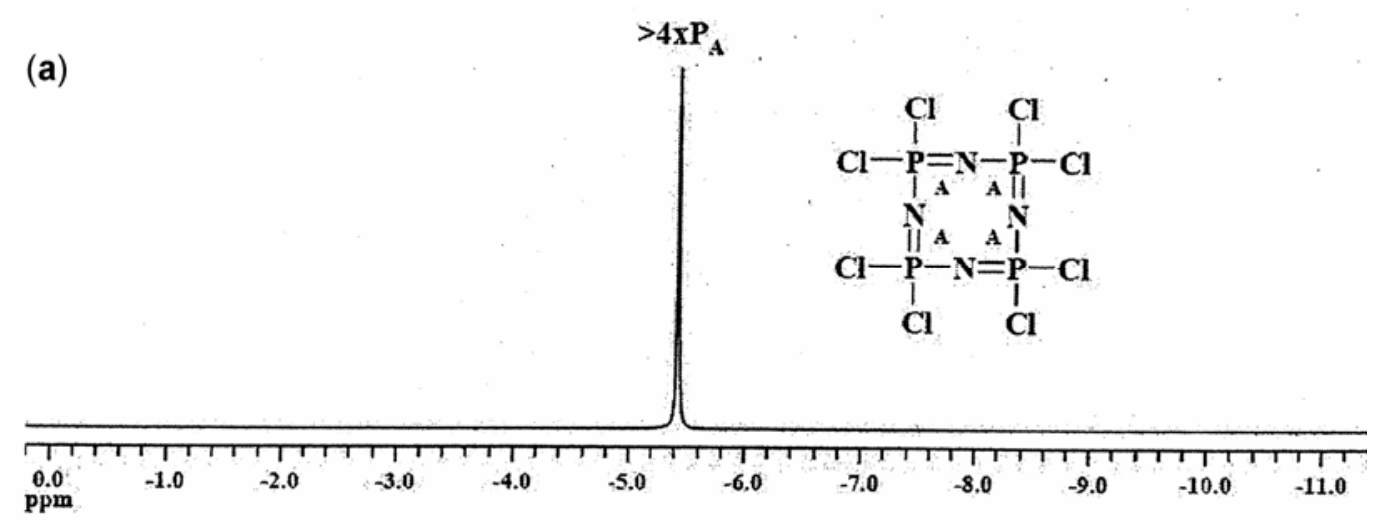

(b)

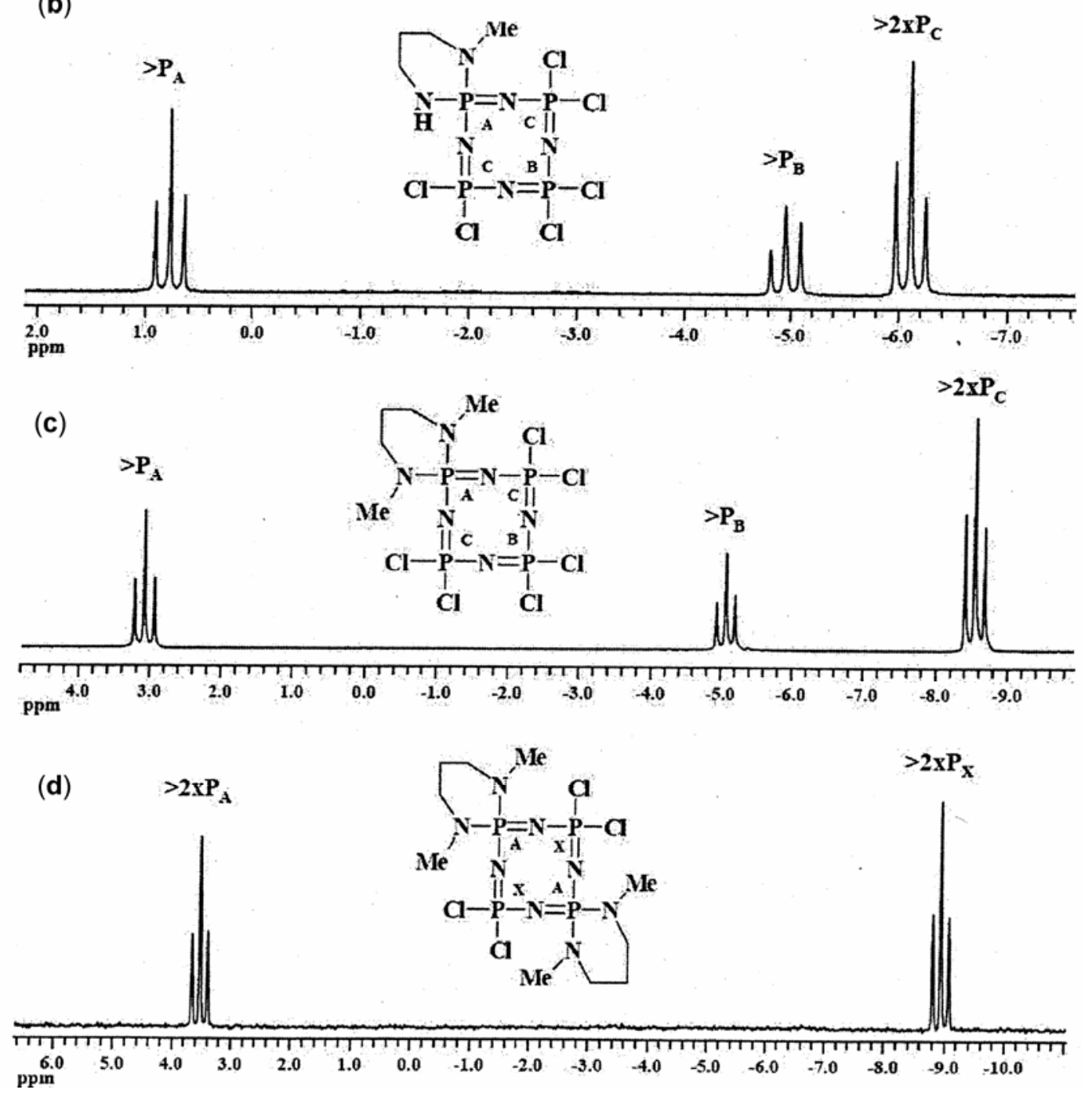

Figure 3. Proton decoupled ${ }^{31}$ P NMR spectra of (a) (1); (b) (3); (c) (5) and (d) (6).

sists of an eight-membered ring, $(\mathrm{PN})_{4}$, with the two $\mathrm{P}$ atoms in the ring being bridged by a macro-ring. The other $\mathrm{P}$ atoms have chloride atoms attached. The maximum separations between the two nonbridged $\mathrm{P}$ atoms in each molecule are $\mathrm{P} 2 \ldots \mathrm{P} 4$
3.902(3) $\AA$ and P7 ... P8 3.973(3) $\AA$. All other $\mathrm{P}$... $\mathrm{P}$ distances in the two molecules are in the ranges 2.829(3)-4.070(3) and 2.856(3)-3.973(3) $\AA$, with means of $3 \cdot 161(3)$ and $3 \cdot 105(3) \AA$, respectively. The $\mathrm{N}$ atoms are displaced above $(+)$ and 


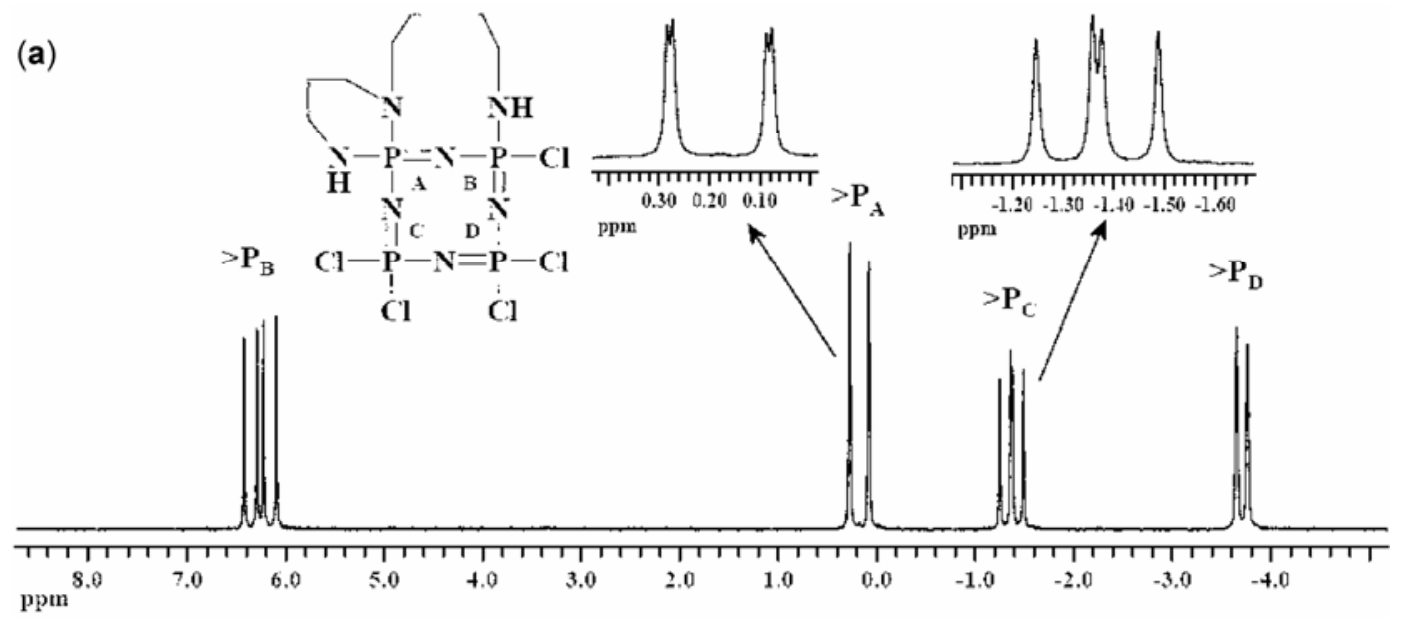

(b)

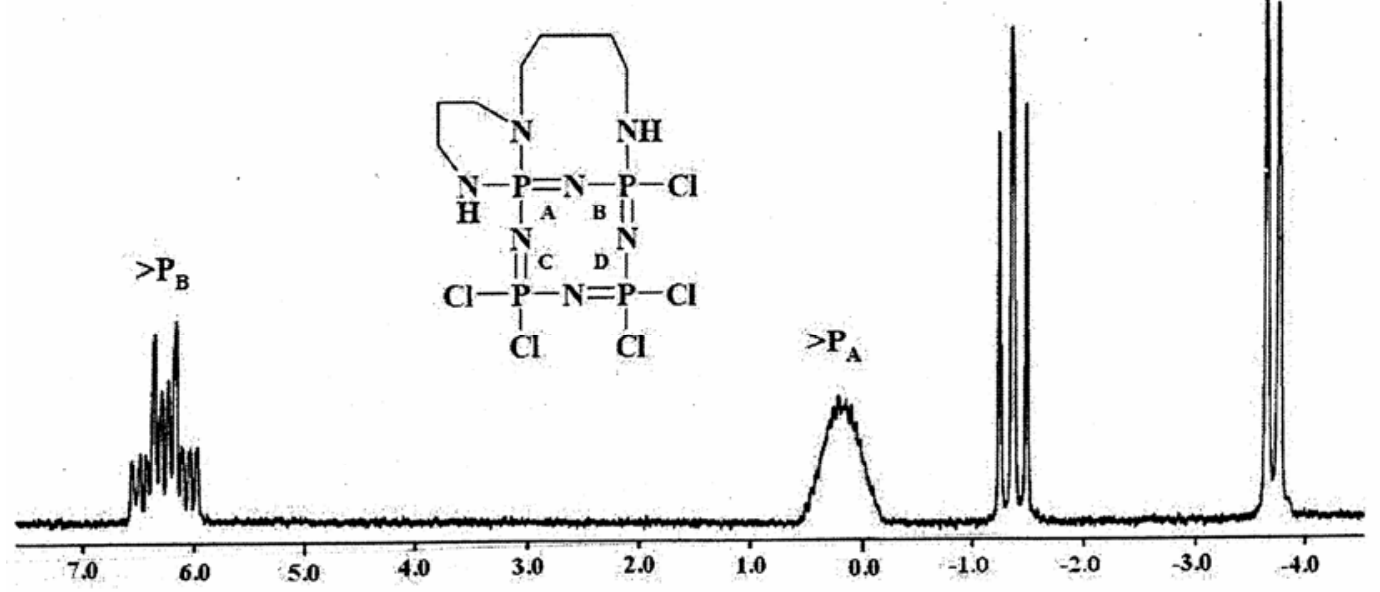

Figure 4. (a) Proton decoupled ${ }^{31} \mathrm{P}$ NMR spectrum of (8); (b) Proton coupled ${ }^{31} \mathrm{P}$ NMR spectrum of (8).

below (-) to the least-squares planes through the $\mathrm{P}$ atoms by the following distances: N1 0.394(2), N2 $0 \cdot 046(3), \mathrm{N} 3-0.259(3), \mathrm{N} 40.023(2)$ and N9 0.555(2), $\mathrm{N} 10-0 \cdot 380(2), \mathrm{N} 110 \cdot 470(2), \mathrm{N} 12-0 \cdot 262(2) \AA$.

The phosphazene rings are not planar, and are twisted (figure $5 \mathrm{a} ; \quad \varphi_{2}=-177.80 \quad(18)^{\circ}, \quad \varphi_{3}=-$ $124 \cdot 26(32)^{\circ}, \theta_{2}=69 \cdot 16(13)^{\circ}$ and $\left.\theta_{3}=111 \cdot 45(35)^{\circ}\right]$ and twisted [figure 5b; $\varphi_{2}=135.05(15)^{\circ}, \varphi_{3}=$ $179 \cdot 15(9)^{\circ}, \theta_{2}=38 \cdot 70(18)^{\circ}$ and $\left.\theta_{3}=95 \cdot 60(9)^{\circ}\right]$ conformations having total puckering amplitudes ${ }^{43} Q_{\mathrm{T}}$ of $0.871(2) \AA$ and 1.465(6) $\AA$, respectively. The sixmembered rings ( $\mathrm{P} 1 / \mathrm{N} 5 / \mathrm{N} 6 / \mathrm{C} 1-\mathrm{C} 3)$, (P3/N7/N8/C $\mathrm{C} 10)$, (P5/N13/N14/C11-C13) and (P6/N15/N16/ C18-C20) are in chair conformations $\left[Q_{\mathrm{T}}=\right.$ $1.085(6) \AA, \varphi_{2}=-32.4(3)^{\circ}$ and $\theta_{2}=122.6(1)^{\circ}$; $Q_{\mathrm{T}}=1.095(8) \AA, \varphi_{2}=143.9(3)^{\circ}$ and $\theta_{2}=53.2(1)^{\circ}$; $Q_{\mathrm{T}}=1.017(7) \AA, \varphi_{2}=-32.7(4)^{\circ}$ and $\theta_{2}=126.1(1)^{\circ}$; $Q_{\mathrm{T}}=0.098(7) \AA, \varphi_{2}=-32.1(4)^{\circ}$ and $\theta_{2}=128.5(1)^{\circ}$, respectively]. As expected, the macrocyclic rings are non-planar with the puckering amplitudes $Q_{\mathrm{T}}$ of $2.233(2) \AA$ and $1.501(2) \AA ; 1.964$ (2) $\AA$ and $1.955(2) \AA$, respectively. The average $\mathrm{P}-\mathrm{N}$ bond lengths in phosphazene rings are 1.573(3) and $1.576(2) \AA$, which are shorter than the average exocyclic P-N bonds of 1.650(2) and 1.657(2) $\AA$, respectively. The sum of the bond angles around the $\mathrm{N}$ atoms in the eleven-membered spiro-cyclic rings are $348.49(18)^{\circ}$ and $346.07(18)^{\circ}$; 350.67(18) and $348.68(18)^{\circ}$, respectively, which approve that the $\mathrm{N}$ atoms in have pyramidal geometries.

According to spectral data of (3), (5), (6), (8), (9) and (11), the compounds (3), (5) and (6) contain a $\mathrm{N}_{4} \mathrm{P}_{4}$ ring with six-membered spiro ring, whereas compound (11) is dispiroansa. On the other hand, spiroansa compounds (8) is tricyclic systems based on a single tetramer unit, six-membered spiro ring and nine-membered ansa ring. Furthermore, the structure of (9) is spirobino. 

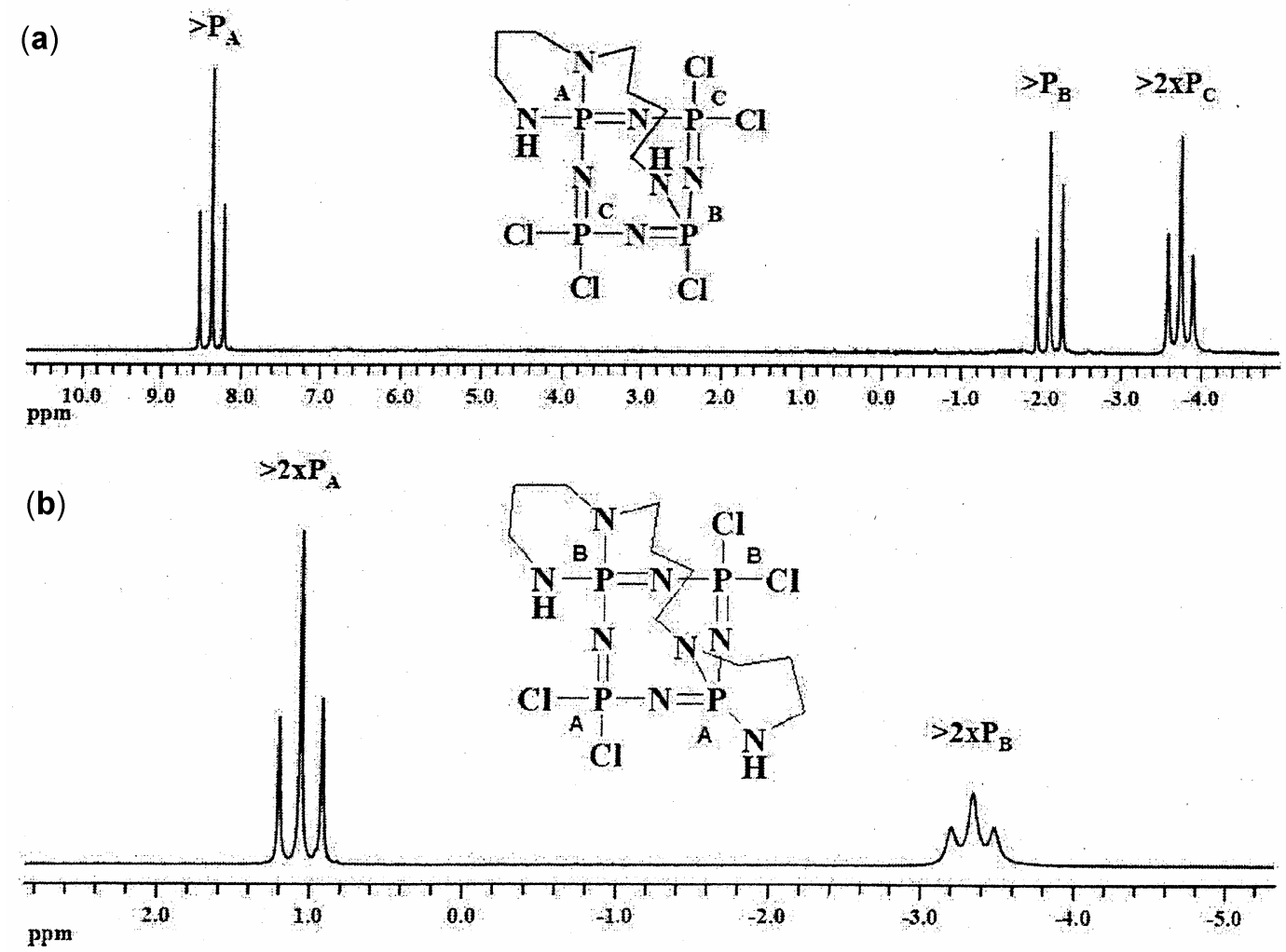

Figure 5. Proton decoupled ${ }^{31} \mathrm{P}$ NMR spectra of (a) (9), (b) (11).

\section{Summary}

The synthesis and characterization of novel monospiro N-methyl-propane-1,3-diamino (3), mono-(5), bis-spiro-N,N'-dimethyl- propane-1, 3-diaminocyclotetraphosphazenes (6), two spiroansa phosphazenes (8) and (9) with spermidine and one dispiroansa cyclotetraphosphazene (11) with spermine were studied. These compounds could be useful as precursors for preparing other models of mixedsubstituent phosphazenes since chiral systems and biological materials show chemotherapeutic or antimicrobial agent behaviours.

Supplementary data on crystallographic data for the structure reported here have been deposit at the CCDC as supplementary data, CCDC No 710330. Copies of the data can be on application to CCDC, 12 Union Road, Cambridge CB2 IEZ, UK. e-mail: deposit@ccdc.cam.ac.uk.

\section{Acknowledgements}

The authors thank the Otsuka Chemical Co. Ltd. for gifts of $\mathrm{N}_{4} \mathrm{P}_{4} \mathrm{Cl}_{8}$ and the Gebze Institute of Techno- logy Research Fund for partial support. We also thank Anadolu University and Medicinal Plants and Medicine Research Center of Anadolu University Eskişehir, for allowing us to use the X-ray facility.

\section{References}

1. Aslan F, Demirpence Z, Tatsız R, Turkmen H, Öztürk A I and Arslan M 2008 Z. Anorg. Allg. Chem. 634 1140

2. Singler R E, Deome A J, Dunn D A and Bieberich M J 1986 Indian Eng. Chem. Prod. Res. Dev. 2546

3. Keller M A and Saba C S 1996 Anal. Chem. 683489

4. Inoue K, Yamauchi T, Itoh T and Ihara E $2007 \mathrm{~J}$. Inorganic and Organometallic Polymers and Material 17367

5. Omotowa B A, Phillips B S, Zabinski J S and Shreeve J M 2004 Inorg. Chem. 43175466

6. Allcock H R and Kim C 1991 Macromolecules 24 2646

7. Huizen A A van der $1984 \mathrm{PhD}$ Thesis, University of Groningen, The Netherlands

8. (a) Allcock H R, Dembek A A, Kim C, Devine R L S, Si Y, Steiner W H and Spangler C W 1991 Macromolecules 24 1000; (b) Bhuvan Kumar N N, Kumara Swamy K C 2008 Chirality 20781

9. Cohen S, Bano W C, Visscher K B, Chow M, Allcock H R and Langer R $1990 \mathrm{~J}$. Am. Chem. Soc. 112 7832 
10. Rule K L, Selvaraj I I and Kirchmeier R L $2001 \mathrm{~J}$. Flourine Chem. 112307

11. Allcock $\mathrm{H} R$, in Wisian-Neilson $\mathrm{P}$, Allcock $\mathrm{H} R$, Wynne K J 1994 (eds) Inorganic and organometallic Polymers II, ACS Symposium Series 572 American Chemical Society, Washington, DC (Chapter 17)

12. Bovin J O, Galy J, Labarre J F and Sournies F 1978 J. Mol. Struct. 49421

13. Cros S, Faucher J P, Francois G, Labarre J F, Levy G and Sournies F Eur. J. Cancer submitted for publication. These tests were performed at-the Laboratoire de Toxicologie et Pharmacologie Fondamentales du CNRS, Toulouse.

14. Yildiz M, Yilmaz S and Dölger B 2007 Russian J. General Chem. 77122117

15. Zanin B, Faucher J P and Labarre J F 1990 Inorganica Chimica Acta 172147

16. Bonnet J P and Labarre J F 1988 Inorganica Chimica Acta 149187

17. İbişoğlu H 2007 Heterocycles 71102173

18. Yenilmez Çiftçi G, Tanrıverdi E and Zorlu Y 2008 Heterocycles $\mathbf{7 5} 3635$

19. Andrews R 1979 IRCS Med. Sci. 7285

20. Guerch G, Labarre J F, Lahana R, Roques R and Sournies F 1983 J. Mol. Struct. 99275

21. Bovin J O, Labarre J F and Galy J 1979 Acta Cryst. B35 1182

22. Cameron T S, Cordes R E and Jackman F A 1979 Acta Cryst. B35 980

23. Krishnamurty S S, Sundaram P M and Woods M 1982 Inorg. Chem. 21406

24. Cameron T S, Cordes R E and Vincent B R 1986 Acta Cryst. C42 1242

25. Deutsch W F, Hursthouse M B, Kılıç Z, Parkes H G, Shaw (Nee Gözen) L S and Shaw R A 1987 Phosphorus and Sulfur and the Related Elements 3281

26. Ihara H, Scherbina M, and Chvalun S $2003 \mathrm{Mol}$. Cryst. Liq. Cryst. 39091
27. Öztürk L, Ișıklan M, Kılıç Z and Hökelek T 2002 Acta Cryst. C58 o80

28. Öztürk L, Hökelek T, Ișıklan M and Kılıç Z 2001 Acta Cryst. C57 1228

29. Krause W E, Parvez M, Visscher K B, Allcock H R 1996 Inorg. Chem. 356337

30. Işıklan M, Kılıç Z, Akduran N and Hökelek T $2003 \mathrm{~J}$. Mol. Struct. 660167

31. Fincham J K and Shaw R A 1990 Phosphorus, Sulfur, and Silicon 47109

32. Kumaraswamy S, Vijjulatha M, Muthiah C, Kumara Swamy K C and Engelhardt U 1999 J. Chem. Soc. Dalton Trans. 891

33. Chandrasekhar V, Krishnamurthy S S, Vasudeva Murthy A R, Shaw R A and Woods M 1981 Inorg. Nucl. Chem. Letts. 117 No. 5/6 181

34. Labarre J F, Guerch G, Sournies F, Lahana R, Enjalbert $\mathrm{R}$ and Galy J $1984 \mathrm{~J}$. Mol. Struct. 11675

35. Kılıç A, Kılıç Z and Shaw R A 1991 Phosphorus, Sulfur and Silicon $\mathbf{5 7} 111$

36. Guerch G,. Labarre J F, Lahana R, Sournies F, Enjalbert R, Galy J and Declercq J P 1984 Inorganica Chimica Acta 83 L33

37. Cameron T S, Linden A, Guerch G, Bonnet J P and Labarre J 1989 J. Mol. Struct. 212295

38. Bruker 1996 SADABS. Bruker AXS Inc., Madison, Wisconsin, USA

39. Sheldrick G M 2008 Acta Cryst. A64 112

40. Farrugia L J 1997 J. Appl. Cryst. 30565

41. Gitel' P O, Osipova L and Solovova O P $1975 \mathrm{Zh}$. Obsh. Khim. $\mathbf{4 5} 1749$

42. (a) Sampath Kumar E, Muralidhara M G, Chandrasekhar V 1995 Polyhedron 1412 1571; (b) Krishnamurty S S and Woods M 1987 Annu. Rep. N.M.R. Spectrosc. 19175 (Academic Press, London)

43. Cremer, D and Pople J A 1975 J. Am. Chem. Soc. 97 1354 